\title{
Bacterial Speck of Tomato ${ }^{1}$
}

\section{Shouan Zhang, Geoffrey Meru, and Ken Pernezny²}

Bacterial speck of tomato, caused by a bacterium Pseudomonas syringae pv. tomato, is a disease of increasing importance to Florida fresh-market tomato production. Although the disease was reported in 1933 in the Bradenton area, there have been few reports of the disease in Florida, possibly because this problem is easily confused with the more common bacterial spot disease. A serious outbreak of bacterial speck was discovered in the winter of 1977-1978 in the Homestead area and was subsequently reported in other parts of the state Florida, including a serious outbreak in St. Lucie County in 2003. A serious outbreak of bacterial speck occurred in the winter and spring of 2010 all over southern Florida, particularly in the Bradenton/Ruskin and Immokalee areas.

\section{Symptoms}

Tentative field diagnosis of bacterial speck is best accomplished by careful inspection of fruit symptoms. Speck lesions on green fruit are small, sunken, black spots surrounded by darker green haloes (Figure 1). On ripe fruit, spots are dark brown to black, superficial flecks (Figure 2). Foliage symptoms of bacterial speck are much more difficult to distinguish from other diseases such as bacterial spot. The leafspots are small, black lesions surrounded by prominent chlorotic (yellow) haloes (Figure 1). These haloes are quite large, averaging twice the size of the necrotic tissue they surround. Lesions in the stems are dark brown to black and shaped like elongated ovals.

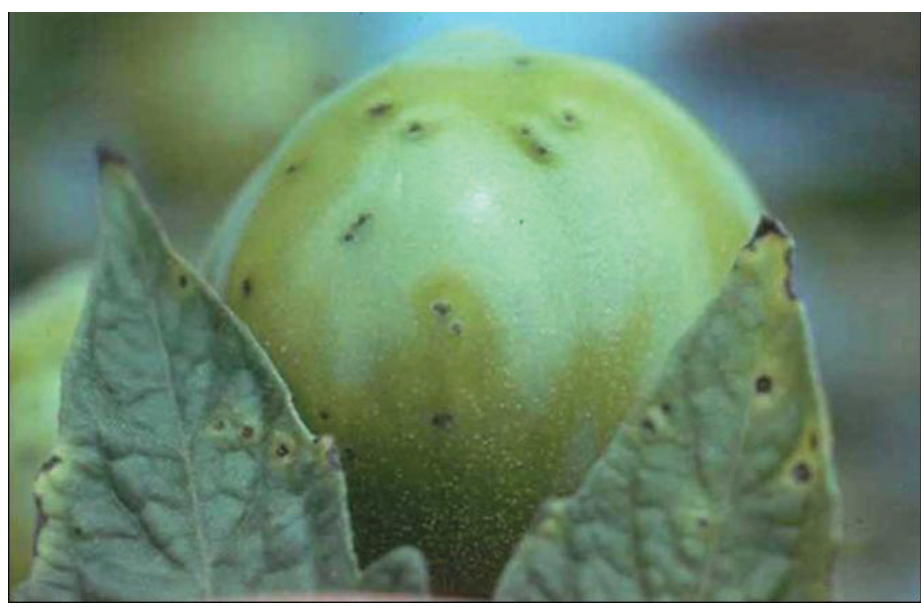

Figure 1. Speck lesions and leafspots on green fruit. Credits: UF/IFAS

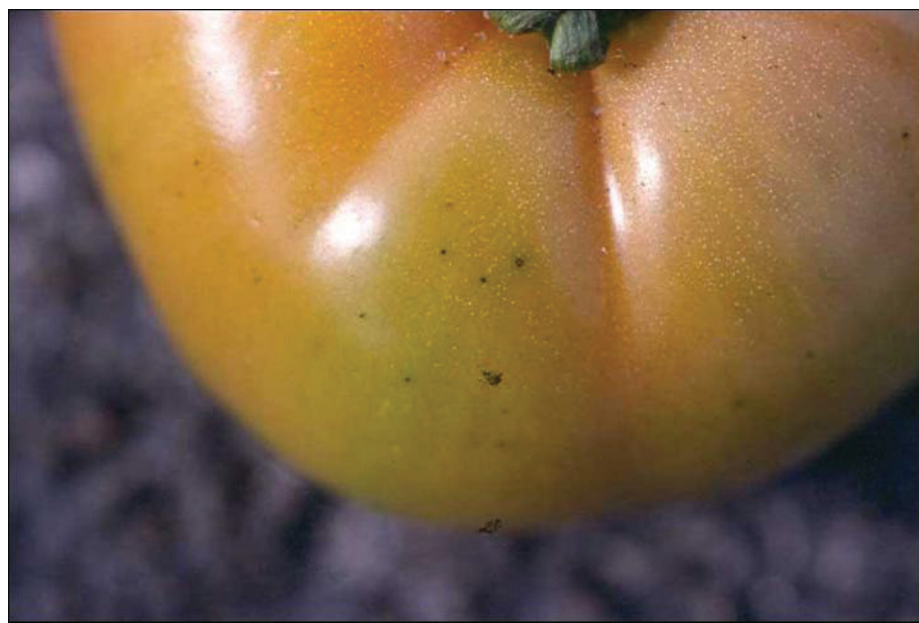

Figure 2. Speck lesions on ripe fruit. Credits: UF/IFAS

1. This document is PP10, one of a series of the Plant Pathology Department, UF/IFAS Extension. Original publication date April 1994 . Revised June 2005 and December 2021. Visit the EDIS website at https://edis.ifas.ufl.edu for the currently supported version of this publication.

2. Shouan Zhang, professor, Plant Pathology Department; Geoffrey Meru, assistant professor, Horticultural Sciences Department, UF/IFAS Tropical Research and Education Center; Ken Pernezny, professor emeritus, Plant Pathology Department, UF/IFAS Everglades Research and Education Center; UF/IFAS Extension, Gainesville, FL 32611.

The Institute of Food and Agricultural Sciences (IFAS) is an Equal Opportunity Institution authorized to provide research, educational information and other services


national origin, political opinions or affiliations. For more information on obtaining other UF/IFAS Extension publications, contact your county's UF/IFAS Extension office. U.S. Department of Agriculture, UF/IFAS Extension Service, University of Florida, IFAS, Florida A \& M University Cooperative Extension Program, and Boards of County Commissioners Cooperating. Nick T. Place, dean for UF/IFAS Extension. 


\section{Epidemiology}

Bacterial speck is favored by cool, moist environmental conditions. The virulent bacteria are spread mechanically and by wind-driven rain. The disease will develop and progress rapidly at $75^{\circ} \mathrm{F}$. However, disease development is readily apparent at $63^{\circ} \mathrm{F}$. Typical symptoms are not evident at $89^{\circ} \mathrm{F}$ as the pathogen populations are severely depleted.

The longer that tomato leaves remain wet, the more likely bacterial populations will build to levels sufficient for production of visible leaf damage. Six hours of continual leaf wetness will promote bacterial speck development. Measurements of 11-13 hours per day of continuous leaf wetness in Florida are not uncommon. Past outbreaks occurred under conditions of unusually high winter rainfall and low temperature. When these conditions are anticipated in the future, bacterial speck epidemics could occur.

Pseudomonas syringae pv. tomato may survive the summer in Florida in very low numbers on the surface of volunteer tomato plants. Survival of this bacterium in the soil is unlikely.

\section{Control}

Use high quality, pathogen free seed or transplants. Tomato residues and volunteer tomato plants should be destroyed immediately after the final harvest to eliminate possible bacteria on plant surfaces. Since P. syringae pv. tomato has a narrow host range, avoidance of tomato double cropping should be helpful in controlling this disease. Avoid working in infected fields when the plants are wet to reduce disease-spread.

No chemicals are registered specifically for bacterial speck. Pesticides applied for bacterial spot control should also provide control for bacterial speck in tomato. Mancozeb and copper tank mixes have been applied for many years in Florida for control of bacterial spot of tomato. 